\title{
Lipids and lipid binding proteins: A perfect match
}

Citation for published version (APA):

Glatz, J. F. C. (2015). Lipids and lipid binding proteins: A perfect match. Prostaglandins Leukotrienes and Essential Fatty Acids, 93, 45-49. https://doi.org/10.1016/j.plefa.2014.07.011

Document status and date:

Published: 01/02/2015

DOI:

10.1016/j.plefa.2014.07.011

Document Version:

Publisher's PDF, also known as Version of record

Document license:

Taverne

Please check the document version of this publication:

- A submitted manuscript is the version of the article upon submission and before peer-review. There can be important differences between the submitted version and the official published version of record.

People interested in the research are advised to contact the author for the final version of the publication, or visit the DOI to the publisher's website.

- The final author version and the galley proof are versions of the publication after peer review.

- The final published version features the final layout of the paper including the volume, issue and page numbers.

Link to publication

\footnotetext{
General rights rights.

- You may freely distribute the URL identifying the publication in the public portal. please follow below link for the End User Agreement:

www.umlib.nl/taverne-license

Take down policy

If you believe that this document breaches copyright please contact us at:

repository@maastrichtuniversity.nl

providing details and we will investigate your claim.
}

Copyright and moral rights for the publications made accessible in the public portal are retained by the authors and/or other copyright owners and it is a condition of accessing publications that users recognise and abide by the legal requirements associated with these

- Users may download and print one copy of any publication from the public portal for the purpose of private study or research.

- You may not further distribute the material or use it for any profit-making activity or commercial gain

If the publication is distributed under the terms of Article $25 \mathrm{fa}$ of the Dutch Copyright Act, indicated by the "Taverne" license above, 
Review

\title{
Lipids and lipid binding proteins: A perfect match
}

\author{
Jan F.C. Glatz* \\ Department of Genetics \& Cell Biology, Cardiovascular Research Institute Maastricht (CARIM), Maastricht University, P.0. Box 616, 6200 MD Maastricht, \\ The Netherlands
}

\section{A R T I C L E I N F O}

\section{Article history:}

Received 1 May 2014

Received in revised form

9 July 2014

Accepted 11 July 2014

\section{Keywords:}

Lipid bio-availability

Lipid binding protein

Fatty acid-binding protein

CD36

Fatty acid signaling

\begin{abstract}
A B S T R A C T
Lipids serve a great variety of functions, ranging from structural components of biological membranes to signaling molecules affecting various cellular functions. Several of these functions are related to the unique physico-chemical properties shared by all lipid species, i.e., their hydrophobicity. The latter, however, is accompanied by a poor solubility in an aqueous environment and thus a severe limitation in the transport of lipids in aqueous compartments such as blood plasma and the cellular soluble cytoplasm. Specific proteins which can reversibly and non-covalently associate with lipids, designated as lipid binding proteins or lipid chaperones, greatly enhance the aqueous solubility of lipids and facilitate their transport between tissues and within tissue cells. Importantly, transport of lipids across biological membranes also is facilitated by specific (membrane-associated) lipid binding proteins. Together, these lipid binding proteins determine the bio-availability of their ligands, and thereby markedly influence the subsequent processing, utilization, or signaling effect of lipids. The bioavailability of specific lipid species thus is governed by the presence of specific lipid binding proteins, the affinity of these proteins for distinct lipid species, and the presence of competing ligands (including pharmaceutical compounds). Recent studies suggest that post-translational modifications of lipid binding proteins may have great impact on lipid-protein interactions. As a result, several levels of regulation exist that together determine the bio-availability of lipid species. This short review discusses the significance of lipid binding proteins and their potential application as targets for therapeutic intervention.
\end{abstract}

(c) 2014 Elsevier Ltd. All rights reserved.

\section{Introduction}

The significance of lipids has generally been recognized throughout the years. Lipids are vital components of many biological processes and serve as building blocks of biological membranes (e.g., phospholipids, sphingolipids) or of specific proteins (e.g., myristoylation, palmitoylation), as substrate for metabolic energy production (longchain fatty acids), and as signaling compounds (long-chain fatty acids and fatty acid metabolites). All lipid species are characterized by their virtual insolubility in aqueous solutions, i.e., their hydrophobic or amphiphilic nature, which property severely hampers the transport of lipids in aqueous compartments such as blood plasma, interstitium and the cellular soluble cytoplasm. However, these compartments contain proteins capable of reversibly and non-covalently binding lipids - therefore designated 'lipid binding proteins' - which dramatically enhance the availability and aqueous transport of specific lipid species. These proteins include a.o. plasma albumin and cytoplasmic lipid binding proteins such as cytoplasmic fatty acid binding proteins

\footnotetext{
*Tel.: + 3143388 1998; fax: + 31433884574

E-mail address: glatz@maastrichtuniversity.nl
}

$\left(\mathrm{FABP}_{\mathrm{c}}\right)$, retinol/retinoic acid binding proteins, and oxysterol binding protein [1-3]. The plasma membrane also contains several proteins capable of reversibly and non-covalently binding long-chain fatty acids, collectively referred to as membrane-associated fatty acid binding proteins [4-6]. Together, the soluble and membraneassociated lipid binding proteins determine the bio-availability of their lipid ligands in a temporal and spatial manner, and thus directly influence the metabolism or signaling effect of these compounds. This short review focuses on the significance of cellular fatty acid binding proteins in health and disease and their potential application as drug targets.

\section{Cytoplasmic fatty acid binding proteins}

The intracellular or cytoplasmic FABPs were first discovered in 1972 [7] and are now known to form a group of 9 distinct proteins of 14-15 kDa with each type displaying a characteristic pattern of tissue distribution $[1,3,8]$. For instance, heart-type FABP $_{c}$ (H-FABP or FABP3) occurs not only in heart but also in (red) skeletal muscle, brain and kidney. Likewise, liver-type $\mathrm{FABP}_{\mathrm{c}}$ (L-FABP or FABP1) is found in both liver, small intestine and kidney. However, intestinal-type $\mathrm{FABP}_{\mathrm{c}}$ 
(I-FABP or FABP2) is specifically expressed in intestinal enterocytes and brain-type FABP (B-FABP or FABP7) specifically in glial cells of the brain. The FABPs are abundantly expressed with cellular concentrations up to $300 \mu \mathrm{M}$ [1]. Similar to plasma albumin, the FABPs each bind (long-chain) fatty acids with such high affinities that the total concentration of fatty acids present in the soluble cytoplasm is enhanced by several orders of magnitude (Fig. 1). Thus, while the estimated non-protein bound fatty acid concentration in the cytoplasm is only $1-5 \mathrm{nM}$, the total fatty acid concentration is up to $50 \mu \mathrm{M}$ (depending of the metabolic state of the cell) [9-11]. As a result, throughout the soluble cytoplasm, cytoplasmic FABP provides a buffer for fatty acids as each fatty acid that is metabolized or undergoes transmembrane transport to another compartment is immediately replenished by the release of another fatty acid from the protein binding site. Therefore, and in view of the small size and free movement of the FABPs through the cytoplasm, a local subcellular deficit of fatty acids is unlikely to occur. Importantly, the abundance of FABP in the soluble cytoplasm $(150-300 \mu \mathrm{M}$ in hepatocytes and cardiomyocytes) presents with a total buffering capacity that markedly exceeds the total fatty acid concentration in each compartment [11] (Fig. 1). The latter assures that the non-protein bound fatty acid concentration remains low, even under mild pathological conditions (e.g. mild ischemia in the heart), so as to keep fatty acids from exerting detrimental effects [12].

The cytoplasmic FABPs can be seen as intracellular counterparts of plasma albumin and function as a sink for fatty acids taken up into the cell. Studies with genetically manipulated mouse models have shown that the absence of cytoplasmic FABPs markedly impairs cellular fatty acid uptake and utilization e.g., [13]. Luiken et al. [14] studied fatty acid uptake into skeletal muscle of mice with either a homozygous or heterozygous deletion of (heart-type) FABP to find that in homozygous mice the fatty acid uptake rate was reduced by approximately $45 \%$ while in skeletal muscle from heterozygous mice, in which the FABP protein expression was $34 \%$ of that of wild-type mice, fatty acid uptake was not altered compared to that in wild-type animals (Fig. 2) [14]. These date indicate that -at least in muscle-cytoplasmic FABP plays an important, yet permissive (rather than a regulatory) role in fatty acid uptake.

The three-dimensional protein structure of the FABPs is almost identical for all nine FABP types $[3,15]$. Common to all FABPs is a 10 -stranded antiparallel $\beta$-barrel structure, which is formed by two orthogonal five-stranded $\beta$-sheets $[16,17]$. The binding pocket is located inside the $\beta$-barrel, the opening of which is framed on one side by an $N$-terminal helix-loop-helix 'cap' domain. Fatty

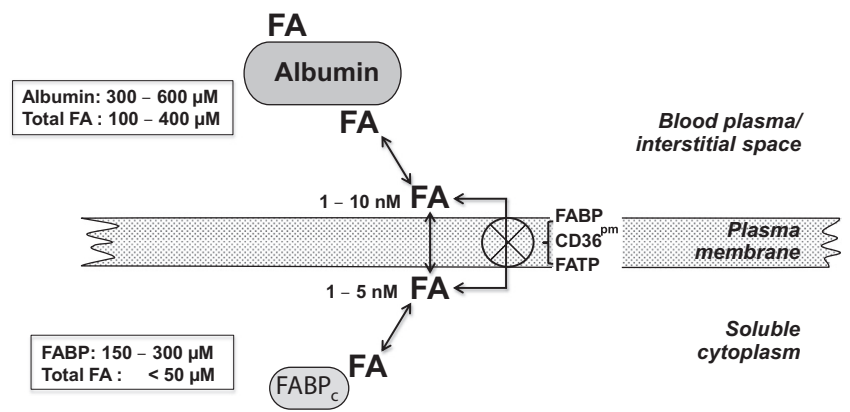

Fig. 1. Schematic presentation of the involvement of various lipid binding proteins in the cellular uptake of long-chain fatty acids. The concentrations of soluble binding proteins, i.e., albumin (68 kDa) in plasma (approximately $600 \mu \mathrm{M}$ ) or interstitial space (approximately $300 \mu \mathrm{M})$, and cytoplasmic FABP $(15 \mathrm{kDa})$ in the cellular cytoplasm, and of (non-protein bound) fatty acids on both sides of the plasma membrane are given (data are for hepatocytes or cardiac myocytes, see [11]). The membrane-associated proteins FABP $_{\mathrm{pm}}$, CD36 and/or FATP assist in the transmembrane transport and subsequent desorption of fatty acids. FA, long-chain fatty acid; $\mathrm{FABP}_{\mathrm{c}}$, cytoplasmic fatty acid-binding protein; $\mathrm{FABP}_{\mathrm{pm}}$, plasma membrane fatty acid-binding protein; FATP, fatty acid transport protein. acids are bound in the interior cavity. The binding pocket of L-FABP is considerably larger than that of the other FABPs, allowing the binding of two fatty acid molecules with differing affinities. Other FABP types bind a single fatty acid molecule.

Pharmacological agents have been developed that interact with the lipid binding by FABPs and thus modify their function. These agents thus may act as tools to provide tissue-specific or cell typespecific control of lipid trafficking or of lipid-signaling pathways (reviewed [17]). For instance, a synthetic inhibitor was developed for adipocyte FABP (A-FABP or FABP4) that, both in vitro and in vivo, markedly influenced the interaction of A-FABP with its ligands in adipocytes and macrophages, thereby acting on metabolic and inflammatory pathways [18]. It was suggested that such chemical inhibition of A-FABP could be a potential therapeutic strategy against insulin resistance, type 2 diabetes, fatty liver disease and atherosclerosis [18]. More recent work by Hoo et al. [19] indeed demonstrated that chronic treatment with this pharmacological compound alleviates both acute liver injury and nonalcoholic steatohepatitis in mice as induced by exposure to a highfat/high-cholesterol diet

\section{Membrane-associated fatty acid binding proteins}

Despite the fact that long-chain fatty acids can easily enter and diffuse within biological membranes, there now is ample evidence that their transport across membranes is facilitated by membraneassociated fatty acid binding proteins (reviewed in [20]). In particular, these membrane proteins facilitate the desorption of the fatty acids from the membrane which represents the ratelimiting step of transmembrane transport [21]. To date, at least three distinct types of membrane proteins have been identified that facilitate the cellular uptake of fatty acids. First, plasma membrane fatty acid-binding protein $\left(\mathrm{FABP}_{\mathrm{pm}}\right)$ is a peripheral protein of approximately $43 \mathrm{kDa}$ with a ubiquitous tissue occurrence [22-24]. Second, a family of so-called 'fatty acid-transport proteins' (FATP; $63 \mathrm{kDa}$ ) consists of 6 members (FATP1-6) each displaying a characteristic tissue distribution [6]. The FATPs are trans-membrane proteins showing acyl-CoA synthetase activity and merely function in the uptake of very long-chain fatty acids (chain length $>22$ ) which then are converted directly into very long-chain acyl-CoA esters [5,6]. Third, CD36, also referred to as fatty acid translocase (FAT), is a class B scavenger receptor protein with multiple functions such as the binding of thrombospondin, oxidized low-density lipoprotein (LDL), and anionic phospholipids, and its action as a gustatory lipid sensor [5,25,26]. CD36 has a hairpin membrane topology with two transmembrane spanning regions, and is heavily glycosylated bringing the 472-amino acid protein $(53 \mathrm{kDa})$ to $88 \mathrm{kDa}$.

With respect to the molecular mechanism of cellular fatty acid uptake (heart, muscle, and adipose tissue), the prevalent view is that the fatty acid transporter CD36 acts as an acceptor for fatty acids wherafter the fatty acids make their way through the cell membrane by simple diffusion. At the inner site of the membrane, the (transmembrane) protein may provide a docking site for $\mathrm{H}$ $\mathrm{FABP}_{\mathrm{c}}$ or for enzymes that act on fatty acids such as acyl-CoA synthetase [5]. Thus, CD36 may function to sequester fatty acids in the membrane, and help organize them within specific membrane domains so as to make the fatty acids readily available for subsequent aqueous transport and/or enzymatic conversion.

At the extracellular site CD36 shows protein-protein interaction with plasma membrane fatty acid-binding protein $\left(\mathrm{FABP}_{\mathrm{pm}}\right)$, and at the intracellular site with cytoplasmic FABP that acts as a lipid chaperone by binding the incoming fatty acids and facilitating their transport to sites of utilization, as discussed above. While FABPpm has been shown to facilitate cellular fatty acid uptake 

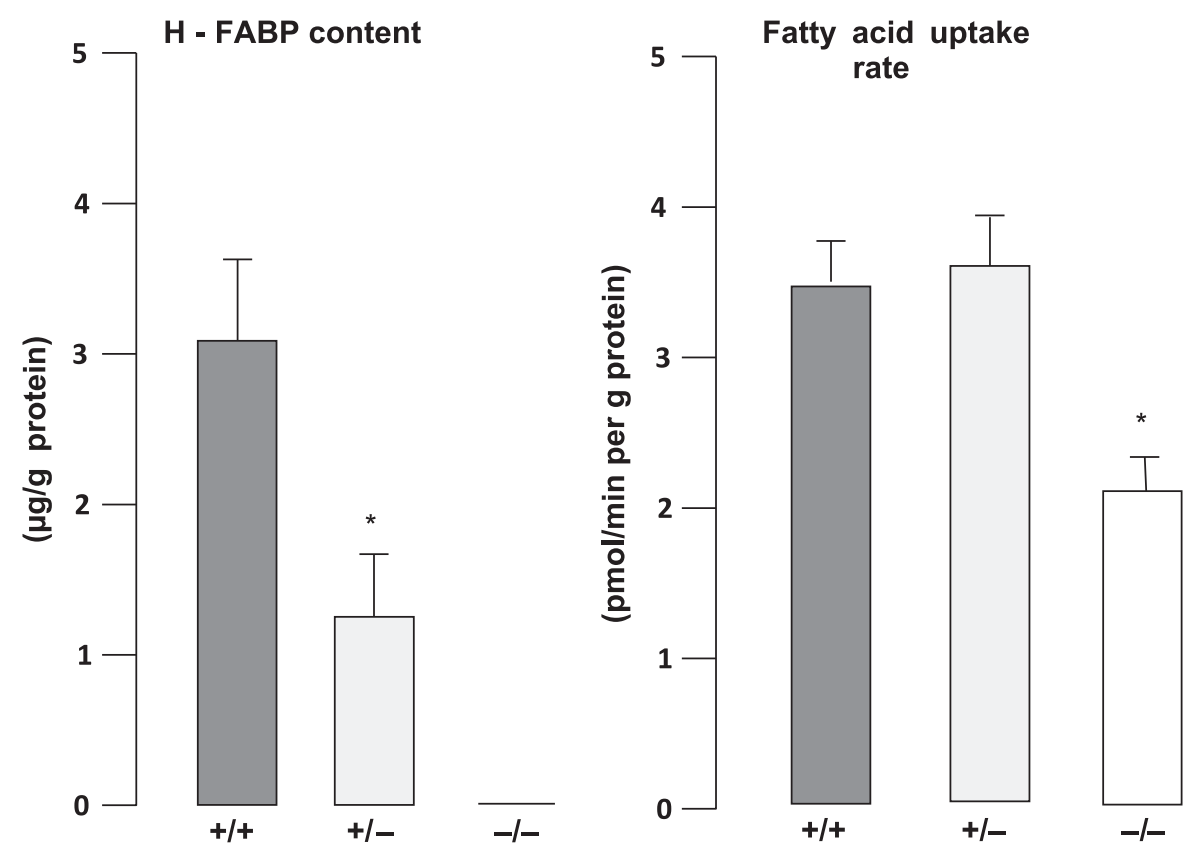

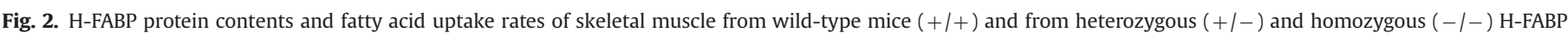

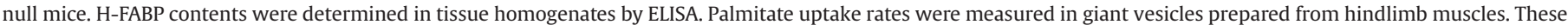

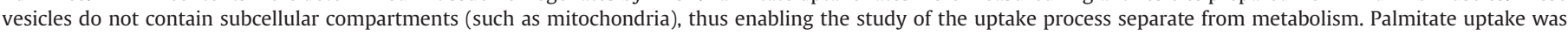

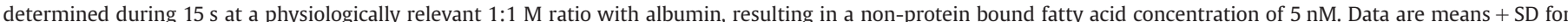

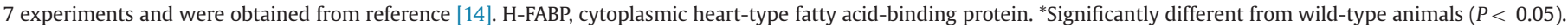

[27], the precise nature of this role is still obscure [5]; for instance, it may function to help create a local high concentration of fatty acids to drive their uptake or to localize CD36 to domains of the plasma membrane where fatty acid uptake preferentially would occur. Such latter role is also envisaged for the caveolins, small integral membrane proteins ( $22 \mathrm{kDa}$ ) that are the defining protein constituents of caveolae (specialized microdomains of the plasma membrane). Caveolins have been suggested to be potential fatty acid transporters [28], but may function in fatty acid uptake in an indirect manner, i.e., by offering plasma membrane docking sites for CD36 [5].

In case of the FATPs, the acyl-CoA synthetase activity of these transporters converts the fatty acids directly into their acyl-CoA ester, resulting in so-called metabolic trapping of fatty acids. This facilitatory action of the FATPs on cellular fatty acid uptake is also referred to as 'vectorial acylation' [6].

CD36 was found not only to facilitate but also to regulate fatty acid uptake in (cardiac and skeletal) muscle by a mechanism that resembles that of GLUT4-mediated cellular glucose uptake [29]. Thus, following an acute stimulus (insulin, muscle contraction) CD36 translocates from an intracellular store (endosomes) to the plasma membrane (Fig. 3). This recycling of CD36, together with the similar recycling of the glucose transporter GLUT4, appears to be pivotal for the proper regulation of cellular substrate uptake, for instance to clear lipids from the circulation postprandially and to rapidly facilitate substrate provision when the metabolic demands of muscle are increased by contractile activity [5]. Recent data indicate that this function of CD36 is controlled not only by intracellular recycling but also by post-translational modification, in particular $N$-glycosylation [30] and ubiquitination [31,32].

Several chronic diseases with genetic and lifestyle components (e.g., dietary factors) are characterized by a perturbed fatty acid (lipid) metabolism. For instance, excess cellular uptake of fatty acids is implicated as early driver in the etiology of lipotoxicity, type 2 diabetes, and heart failure. Evidence is accumulating that these conditions can be treated by the acute or chronic (partial) inhibition of CD36-mediated transport. For example, pharmacological inhibition of CD36 transport by the small molecules AP5055 and AP5258 ameliorated atherosclerosis (46\% decrease in plaque volume) and diabetes (50\% decrease in plasma glucose) in rodent models, with potent reductions in blood triacylglycerol concentrations [33]. Similarly, the CD36 peptide ligand EP 80317 protected against ischemic myocardial injury in mice [34], while antibody inhibition of CD36 improved cardiomyocyte function in a cell model of high-fat induced insulin resistance by metabolic modulation towards glucose utilization rather than fatty acids [35]. Interestingly, complete genetic deficiency of CD36 in humans is mostly asymptomatic [36], suggesting that its pharmacological inhibition would not be harmful yet lead to a redistribution of lipids in the body that is beneficial to the functioning of key organs like heart and liver without affecting other organs.

\section{Concluding remarks}

A dynamic interplay exists among lipids and their cognate binding proteins. These lipid binding proteins act as chaperones for their lipid ligands, facilitating their transport in aqueous environments as well as across (and perhaps within) biological membranes thereby determining their bio-availability. Importantly, lipid binding proteins also protect against potentially detrimental effects of high concentrations of lipids (e.g., the detergent-like action of long-chain fatty acids). It is clear that the functioning of lipids in the various biological pathways (metabolism, signaling, etc.) in both invertebrates and mammals cannot be considered without taking these lipid binding proteins into account. It will be a challenge for the future to unravel further the dynamic interplay among the various lipid species and their metabolites with the various lipid binding proteins under both health and disease conditions. The complexity of these studies can be illustrated from recent insights that the functioning of the lipid binding proteins is controlled at several levels. For instance, the cellular expression of CD36 is under the control of lipid-responsive genes, its trafficking towards and from the plasma membrane is 

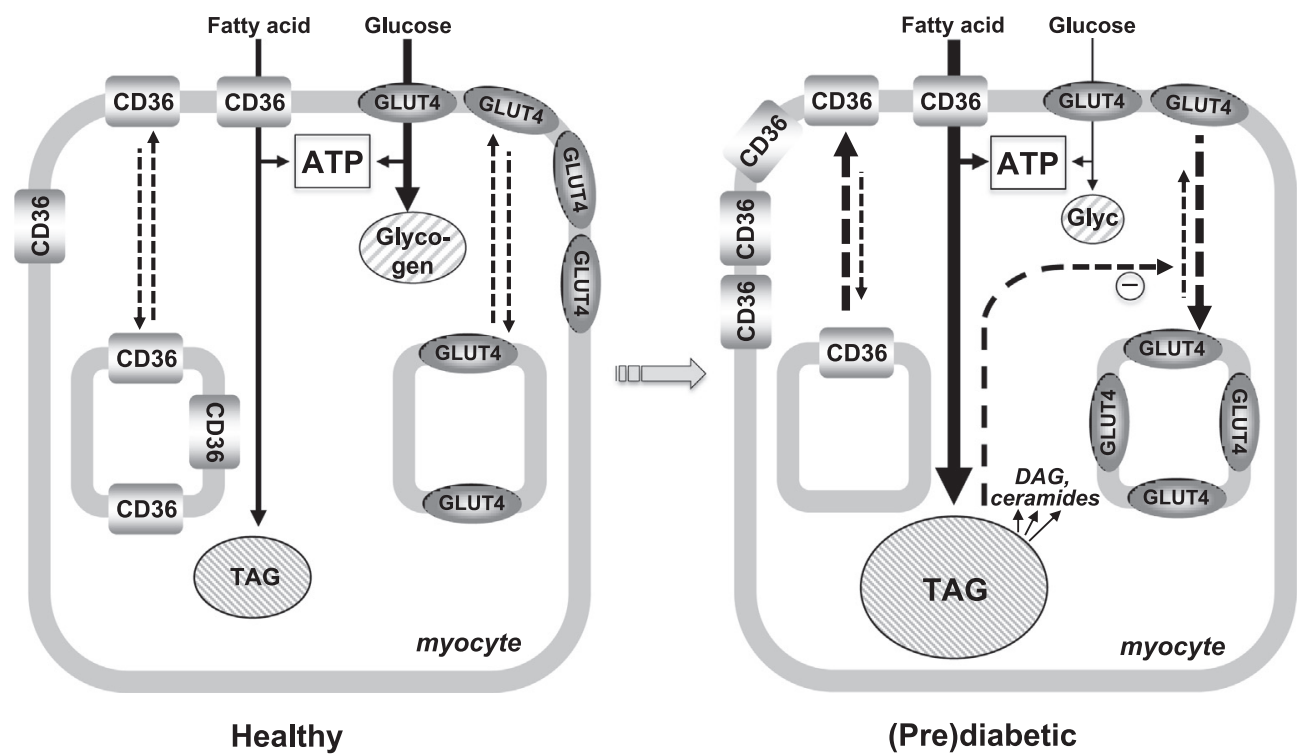

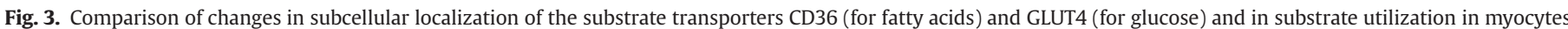

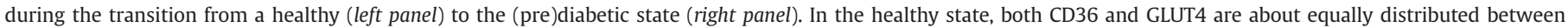

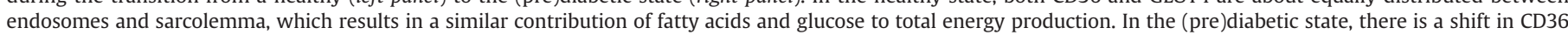

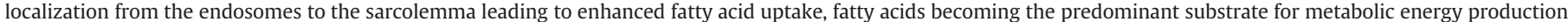

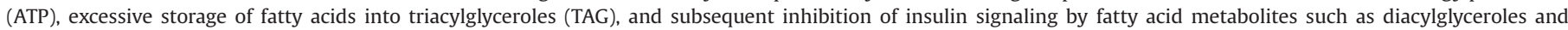

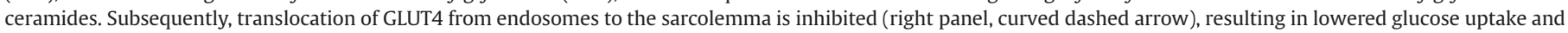
decreased incorporation into glycogen. At that stage, the muscle has become insulin resistant.

governed by hormonal (insulin) and mechanical (muscle contraction) stimuli, while its facilitatory action on cellular fatty acid uptake is regulated a.o. by post-translational modifications including glycosylation, palmitoylation and ubiquitination of the protein. Adding to the complexity is the fact that the various ligands of CD36 (thrombospondin, oxidized LDL, and various long-chain fatty acid species) may compete for the same extracellular hydrophobic binding pocket of the protein [5]. Once more insight has been obtained in these additional aspects it will be possible to design therapies to selectively modulate the actions of lipid binding proteins. As outlined above, a number of recent studies already indicate the feasibility of applying small molecule inhibitors directed against specific lipid binding proteins to rectify aberrant lipid metabolism and inflammation occurring in chronic disease.

\section{References}

[1] J.F.C. Glatz, G.J. Van der Vusse, Cellular fatty acid-binding proteins: their function and physiological significance, Prog. Lipid Res. 35 (1996) 243-282.

[2] F.G. Schaap, G.J. Van der Vusse, J.F.C. Glatz, Evolutuion of the family of intracellular lipid binding proteins in vertebrates, Mol. Cell. Biochem. 239 (2002) 69-77.

[3] J. Storch, A.E. Thumser, Tissue-specific functions in the fatty acid-binding protein family, J. Biol. Chem. 285 (2010) 32679-32683.

[4] X. Su, N.A. Abumrad, Cellular fatty acid uptake: a pathway under construction, Trends Endocrinol. Metab. 20 (2009) 72-77.

[5] J.F.C. Glatz, J.J.F.P. Luiken, A. Bonen, Membrane fatty acid transporters as regulators of lipid metabolism: implications for metabolic disease, Physiol. Rev. 90 (2010) 367-417.

[6] M. Kazantzis, A. Stahl, Fatty acid transport proteins, implications in physiology and dieases, Biochim. Biophys. Acta 2012 (1821) 852-857.

[7] R.K. Ockner, J.A. Manning, R. Poppenhausen, W. Ho, A binding protein for fatty acids in cytosol of intestinal mucosa, liver, myocardioum and other tissues, Science 177 (1972) 56-58.

[8] R.L. Smathers, D.R. Petersen, The human fatty acid-binding protein family: evolutionary divergences and functions, Hum. Genome 5 (2011) 170-191.

[9] H. Vorum, R. Brodersen, U. Kragh-Hansen, A.O. Pedersen, Solubility of longchain fatty acids in phosphate buffer at pH 7.4, Biochim. Biophys. Acta 1126 (1992) 135-142.

[10] G.V. Richieri, A.M. Kleinfeld, Unbound free fatty acid levels in human serum, J. Lipid Res. 36 (1995) 229-240.

[11] M.M. Vork, J.F.C. Glatz, G.J. Van der Vusse, On the mechanisms of long chain fatty acid transport in cardiomyocytes as facilitated by cytoplasmic fatty acidbinding protein, J. Theor. Biol. 160 (1993) 207-222.
[12] J.F.C. Glatz, J.J.F.P. Luiken, F.A. Van Nieuwenhoven, G.J. Van der Vusse, Molecular mechanism of cellular uptake and intracellular translocation of fatty acids, Prostaglandines Leukot. Essent. Fatty Acids 57 (1997) 3-9.

[13] F.G. Schaap, B. Binas, H. Danneberg, G.J. Van der Vusse, J.F.C. Glatz, Impaired longchain fatty acid utilization by cardiac myocytes isolated from mice lacking the heart-type fatty acid-binding protein gene, Circ. Res. 85 (1999) 329-337.

[14] J.J.F.P. Luiken, D.P.Y. Koonen, W.A. Coumans, M.M.A.L. Pelsers, B. Binas, A. Bonen, J.F.C. Glatz, Long-chain fatty acid uptake by skeletal muscle is impaired in homozygous, but not heterozygous, heart-type-FABP null mice, Lipids 38 (2003) 491-496.

[15] A. Reese-Wagoner, J. Thompson, L. Banaszak, Structural properties of the adipocyte lipid binding protein. Review, Biochim. Biophys. Acta 1441 (1999) 106-116.

[16] A. Chmurzynska, The multigene family of fatty acid-binding proteins (FABPs): function, structure and polymorphism, J. Appl. Genet 47 (2006) 39-48.

[17] M. Furuhashi, G.S. Hotamisligil, Fatty acid-binding proteins: role in metabolic diseases and potential as drug targets, Nat. Rev. 7 (2008) 489-503.

[18] M. Furuhashi, G. Tuncman, C. Görgün, L. Makowski, G. Atsumi, E. Vaillancourt, K. Kono, V.R. Babaev, S. Fazio, M.F. Linton, R. Sulsky, J.A. Robl, R.A. Parker, G. S. Hotamisligil, Treatment of diabetes and atherosclerosis by inhibiting fattyacid-binding protein aP2, Nature 447 (2007) 959-965.

[19] R.L.C. Hoo, I.P.C. Lee, M. Zhou, J.Y.L Wong, X. Hui, A. Xu, K.S.L. Lam, Pharmacological inhibition of adipocyte fatty acid binding protein alleviates both acute liver injury and non-alcoholic steatohepatitis in mice, J. Hepatol. 58 (2013) 358-364.

[20] A. Bonen, A. Chabowksi, J.J.F.P. Luiken, J.F.C. Glatz, Mechanisms and regulation of protein-mediated cellular fatty acid uptake: molecular, biochemical and physiological evidence, Physiology 22 (2007) 15-28.

[21] J.A. Hamilton, New insights into the roles of proteins and lipids in membrane transport of fatty acids, Prostaglandines Leukot. Essent. Fatty Acids 77 (2007) 355-361.

[22] W. Stremmel, G. Strohmeyer, F. Borchard, S. Kochwa, P.D. Berk, Isolation and partial characterization of a fatty acid binding protein in rat liver plasma membranes, Proc. Natl. Acad. Sci. U.S.A 82 (1985) 4-8.

[23] C. Roepstorff, J.W. Helge, B. Vistisen, B. Kiens, Studies of plasma membrane fatty acid-binding protein and other lipid-binding proteins in human skeletal miscle, Proc. Nutr. Soc. 63 (2004) 239-244.

[24] A.K. Dutta-Roy, Transport of fatty acids across the human placenta: a review Prog. Lipid Res. 48 (2009) 52-61.

[25] R.L. Silverstein, M. Febbraio, CD36, a scavenger receptor involved in immunity, metabolism, angiogenesis, and behavior, Sci. Signal. 2 (2009) re3.

[26] P. Degrace-Passilly, P. Besnard, CD36 and taste of fat, Curr. Opin. Clin. Nutr. Metab. Care 15 (2012) 107-111.

[27] D.C. Clarke, D. Miskovic, X.X. Han, J. Calles-Escandon, J.F.C. Glatz, J.J.F.P. Luiken, J.J. Heikkila, A. Bonen, Overexpression of membrane associated fatty acid binding protein (FABPpm) in vivo increases fatty acid sarcolemmal transport and metabolism, Physiol. Genomics 17 (2004) 31-37.

[28] W. Stremmel, L. Pohl, A. Ring, T. Herrmann, A new concept of cellular uptake and intracellular trafficking of long-chain fatty acids, Lipids 36 (2001) 981-989. 
[29] A. Bonen, J.J.F.P. Luiken, Y. Arumugam, J.F.C. Glatz, N.N. Tandon, Acute regulation of fatty acid uptake involves the cellular redistribution of fatty acid translocase, J. Biol. Chem. 275 (2000) 14501-14508.

[30] B. Lauzier, C. Merlen, F. Vaillant, J. McDuff, B. Bouchard, P.C. Beguin, V. W. Dolinsky, S. Foisy, L.R. Villeneuve, F. Labarthe, J.R.B. Dyck, B.C. Allen, G. Charron, C. Des Rosiers, Post-translocational modifications, a key process in CD36 function: lessons from the spontaneously hypertensive rat heart, J. Mol. Cell. Cardiol. 51 (2011) 99-108.

[31] J. Smith, X. Su, R. El-Maghrabi, P.D. Stahl, N.A. Abumrad, Oppositie regulation of CD36 ubiquitination by fatty acids and insulin, J. Biol. Chem. 283 (2008) 13578-13585.

[32] K.-Y. Kim, M.V. Stevens, M.H. Akter, S.E. Rusk, R.J. Huang, A. Cohen, A. Noguchi, D. Springer, A.V. Bocharov, T.L. Eggerman, D.-F. Suen, R.J. Youle, M. Amar, A. T. Remaley, M.N. Sack, Parkin is a lipid-responsive regulator of fat uptake in mice and mutant human cells, J. Clin. Invest. 121 (2011) 3701-3712.
[33] A. Geloen, L. Helin, B. Geeraert, E. Malaud, P. Holvoet, G. Marguerie, CD36 inhibitors reduce postprandial hypertriglyceridemia and protect against diabetic dyslipidemia and atherosclerosis, PloS One 7 (2012) e37633.

[34] V.L. Bessi, S.M. Labbé, D.N. Huynh, L. Ménard, C. Jossart, M. Febbraio, B. Guérin, M. Bentourkia, R. Lecomte, A.C. Carpentier, H. Ong, S. Marleau, EP 80317, a selective CD36 ligand, shows cardioprotective effects against post-ischaemic myocardial damage in mice, Cardiovasc. Res. 96 (2012) 99-108.

[35] Y. Angin, L.K.M. Steinbusch, P.J. Simons, S. Greulich, N.T.H. Hoebers, K. Douma, M.A.M.J. Van Zandvoort, W.A. Coumans, W. Wijnen, M. Diamant, D.M. Ouwens, J.F.C. Glatz, J.J.F.P. Luiken, CD36 inhibition prevents lipid accumulation and contractile dysfunction in rat cardiomyocytes, Biochem. J. 448 (2012) 43-53.

[36] M. Febbraio, E. Guy, C. Coburn, F.F. Knapp, N.A. Abumrad, R.L. Silverstein, The impact of overexpression and deficiency of fatty acid translocase (FAT)/CD36, Mol. Cell. Biochem. 239 (2002) 193-197. 